\title{
Kahoot! Application in Medical Education: Quality of Lectures Improvement
}

\author{
Galuh Suryandari ${ }^{1, *}$ \\ ${ }^{1}$ Lecturer of School of Medicine FMHS Universitas Muhammadiyah Yogyakarta, Yogyakarta, Indonesia \\ *Corresponding author. Email: galuhsuryandari@umy.ac.id
}

\begin{abstract}
Efforts to improve the quality of lectures with technology implementation are increasingly needed to overcome the problems of large-scale classes, one of them are Kahoot!. It aims measure and compare the improvement quality of lectures between the biomedical and clinical science groups on medical school of FMHS UMY after the implementation of Kahoot! This study used Non-control quasi-experimental pre-post-test method with total sampling. Quality of Lectures questioner had been declared and validated by Quality Assurance Unit School of Medicine FMHS UMY. The data analysis method uses a paired t-test followed by an unpaired t-test. The result of paired t-test showed an increase of $7.4 \%(p=0.001), 7 \%(p=0.005), 7.2 \%(p=0.003)$ and $6.97 \%(p=0.085)$ on aspects of the quality of lecture material, delivery methods, communication \& interactions, and class schedules \& facilities, in sequence. The Results of unpaired t-test showed that there were insignificantly differences in quality improvement between the biomedical and clinical science groups ( $p>0.05$ ). There was a significant improvement in all four aspects of lecture quality after the implementation of Kahoot! Quality improvement in the biomedical science group was insignificantly better than clinical science.
\end{abstract}

\section{Keywords: Biomedical, Clinical, Kahoot! Medical Students, Quality Lectures}

\section{INTRODUCTION}

The development of education has experienced major changes due to advances in information and communication technology. Along with these developments, the learning methods used in the teaching and learning process of medical student also develop. Severe challenges faced in the learning process of medical students have in common in various countries in Asia. Many medical education institutions that still use the single lecture method based on biomedical and clinical science disciplines are not integrated yet. The learning process is still problematic in large-scale classess and spends most of the time in traditional lectures. The problem that arises is the lack of students' independence in learning.[1]

Kahoot! application can be one of the media to support the learning process for large-scale classes. Now Kahoot! is develop its use into an application that allows a teacher to make quizzes related to the material presented and display the result of student participation quickly and easily.[2] Kahoot! has an attractive user interface so that it can increase student interest in completing quizzes given by lecturer.[3]

Some previous studies have shown that the using of Kahoot! increase students' concentration, pleasure, acceptance of material, motivation and satisfaction than other application platforms. [4,10] The using of Kahoot! can lead to students' participation in learning so that it is expected to improve the quality of the learning process, especially in large classes. There is a lack from some previous study which is comparing the quality of lectures between groups of lecturers based on biomedical and clinical science disciplines after the application of the Kahoot! quiz application. Based on that reason, the novelty of this research was examining comparison of the quality of lectures after using Kahoot! between biomedical science and clinical sciences group of lectures at the Medical Study Program FMHS Universitas Muhammadiyah Yogyakarta.

\section{RESEARCH METHOD}

This research is a quantitative study with a quasi-pre-testpost-test experimental research design. The sampling technique used total sampling. The research instrument was in the form of a questionnaire developed by Quality Lectures from the Medical Study Program Quality Team of FKIK UMY, which had been tested for validity and reliability with a Cronbach's Alpha value of 0.822. The questionnaire contained ten questions regarding four aspects of the Quality of lectures, namely lecture material, delivery methods, communication \& interaction, and class schedules \& facilities which was filled by the students.

Data was collected twice, namely before and after the application of Kahoot! from the same lecturer partners. Data before implementation was obtained from the quality assurance team of the School of medicine FKIK UMY. Lecturer partners were applying the application Kahoot! quiz during their lecture as a process of learning. Data collection after the application of Kahoot! was conducted by asking students to fill in the same questionnaire at the end of the lecture from October 2018 to April 2019. 
The population of this research was students of school of medicine FMHS UMY batch 2015, 2016, 2017, and 2018 who participated in partner lecturer lecture. Inclusion criteria in the research were students who are registered as active students and were willing to become research respondents. The exclusion criteria in this research were students who repeated blocks, did not attend lectures, and could not log in on the Kahoot! application.

\section{RESULTS AND DISCUSSION}

The data was obtained from 302 students from batch 2015, 2016, 2017 and 2018. This research was compared four aspects of the quality of lectures from 18 lecturers which delivered a lectured on 7 topics of biomedical science and 9 topics of clinical science.

In the aspect of Lesson Material increased by 0.36 (with a significance of 0.001), in the Delivering Method aspect increased by 0.35 (with a significance of 0.005), the Communication \& Interaction aspect experienced an increase of 0.35 (with a significance of 0.003 ), and in the Lecture \& Facilities Schedule aspect an increased of 0.24 (with a significance of 0.085 ).

Table 1. Paired t-test results for filling out the lecture quality questionnaire before and after the Kahoot!

\begin{tabular}{|c|c|c|c|}
\hline \multirow{2}{*}{ Quality Aspect } & \multicolumn{2}{|c|}{$\begin{array}{c}\text { Average score before } \\
\text { and after Kahoot! } \\
\text { Implementation }\end{array}$} & \multirow{2}{*}{ Sig } \\
\cline { 2 - 3 } & Biomedical & Clinic & \\
\hline Lesson material & 0.519 & 0.237 & 0.102 \\
\hline Delivering method & 0.444 & 0.278 & 0.446 \\
\hline $\begin{array}{c}\text { Communication } \\
\text { and Interaction }\end{array}$ & 0.517 & 0.212 & 0.118 \\
\hline $\begin{array}{c}\text { Schedule and } \\
\text { Facilities }\end{array}$ & 0.417 & 0.112 & 0261 \\
\hline
\end{tabular}

Based on paired t-tests conducted, it was found that the quality aspects of Lesson Material, Delivering Method, and Communication \& Interaction had a value of $p<0.05$ so that it can be concluded that there was a significant improvement between the three aspects of the quality of the lecture before and after the application of the Kahoot! quiz. In the aspect of schedule \& facilities increased by 0.24 but not significant (with a significance of 0.085).

To find out the differences in the quality improvement of lectures between the biomedical and clinical science groups, an unpaired t-test was conducted on the difference in each aspect of lecture quality before and after the application of Kahoot! application.
Table 2. Results of unpaired t-tests for the quality of lectures in the biomedical and clinical sciences group.

\begin{tabular}{|c|c|}
\hline Quality aspect & Sig \\
\hline Lesson material & 0.001 \\
\hline Delivering method & 0.005 \\
\hline Communication and Interaction & 0.003 \\
\hline Schedule and Facility & 0.085 \\
\hline
\end{tabular}

Based on the table, it was found that the quality of lecturers' lectures after the application of the Kahoot! from the lecturer of the biomedical section is better than the lecturer from the clinical part. But the significance value is $>0.05$, so the difference is not statistically significant.

Based on the correlative test conducted in this study, it was found that there was a significant influence in improving the quality of lectures after the Kahoot! application. There are several things that affected the improvement of the quality of lectures in this study related to lecture material, delivery methods, and communication by lecturers. The first aspect of the quality of lectures is assessed from interesting lecture material and used good examples or illustrations. Kahoot!, in its application, can display images and videos making it easier for students to illustrate the material being studied. Use the Kahoot! app can create enthusiasm in the classroom, encourage students to recall lecture material, and create a pleasant classroom environment.[5] This is in accordance with this research where there was an increase in the subject matter aspects after the application of Kahoot! quiz application.

The quality of lectures is also assessed from the aspect of the method of delivering the material by lecturers, including presentation media that are interesting and easy to understand. Kahoot! as a user-friendly medium that makes lectures more interactive and enjoyable; thus, sharper focus and active student participation are needed. The use of Kahoot! application can measure students' understanding of learning material so that it helps improve student academic achievement.[6]

Kahoot! application in its application includein quiz game-based learning methods where the quiz is done in the classroom after the delivery of material by the llecturers. Such a method can involve active participation and competitiveness between students, thereby increasing interaction between teacher and students as well as students. Even the level of student satisfaction in general is very good with the application of the Kahoot! [7] The quiz game method compared to didactic lecture. The quiz game method is preferred and accepted by students because it is more fun and helps students in the process of understanding and remembering material.[8] After the implementation of 
the Kahoot! application can increase in the quality of lectures was found in the aspects of Communication \& Interaction

Timeliness and duration of lectures and facilities in the lecture also be included an assessment of the quality of lectures from the aspects of the Lecture Schedule \& Facilities. Kahoot! effectively was used as an assessment before learning began, so the duration of learning becomes more effective because students have prepared material to be taught before learning begins.[9] Whereas in this study, with the Kahoot! at the end of the lecture, it may be related to the efficiency of the lecture. The lecturer will prepare a few minutes before the lecture ends to use the Kahoot! application so it will affect the timeliness of the lectures.

\section{CONCLUSION}

There are some things that can be concluded from this study. For the firstly, the implementation of The Kahoot! quiz application in the single class lecture process significantly increases the quality of lecture material, quality of the material delivery method, and quality of communication and interaction. It is different from these three aspects. The schedule and facilities aspect does not improve. Then when it seen from the quality of lectures between the groups, it can be concluded that the group of lecturers from the biomedical section is better than the group of lecturers from the clinical science department. But it is not significant.

Further researchers need to prepare the quality of material from each lecturer before the implementation of the Kahoot! Quiz application, conduct better supervision in filling out the lecture quality questionnaire after the application of Kahoot! quiz application. Besides, the larger sample should be considered.

\section{ACKNOWLEDGMENTS}

We thank to dr. Ivanna Beru B. Sp. OG (K). Fer; dr. Denny Anggoro P, M. Sc.; dr. Muhammad Khotibuddin, MPH; dr. Meiky Fredianto, Sp. OT(K); dr. Bambang Edi S., Sp. A.,M . Kes; dr. Dirwan Suryo Soularto, Sp. F., M. Sc; dr. Iman Permana, M. Kes; dr. Hidayatul Kurniawati, M. Sc; dr. Oryzati Hilman, M. Sc., CMFM; Rr. Yuningtyaswari, S. Si., M . Kes; Dr. Dra. Lilis Suryani, M. Kes ; Dr. dr. Sri Sundari, M . Kes; dr. Ika Setyawati, M. Sc; dr. Agus Widyatmoko, Sp.PD .,M. Sc; dr. Adang M . Gugun, Sp. PK ; dr. Suryanto, Sp. PK and dr. Ardi Pramono, M. Kes., Sp. An for implementing Kahoot! on their lecture.

\section{REFERENCES}

[1] SADEGHI, R.; SEDAGHAT, M. M.; SHA AHMADI, F. Comparison of the Effect of Lecture and Blended Teaching Methods on Students' Learning and Satisfaction. J Adv Med Educ Prof 2014, 2 (4), 146150 .
[2] Siegle, D. Technology: Learning Can Be Fun and Games. Gifted Child Today 2015, 38 (3), 192-197. https://doi.org/10.1177/1076217515583744.

[3] Department of Medical Education, School Medical Sciences, Universiti Sains Malaysia, Kelantan, Malaysia; Ismail, M. A.-A.; Mohammad, J. A.-M.; Department of Medical Education, School Medical Sciences, Universiti Sains Malaysia, Kelantan, Malaysia. Kahoot: A Promising Tool for Formative Assessment in Medical Education. EIMJ 2017, 9 (2),19-26. https://doi.org/10.21315/eimj2017.9.2.2.

[4] Chaiyo, Y.; Nokham, R. The Effect of Kahoot, Quizizz and Google Forms on the Student's Perception in the Classrooms Response System. In 2017 International Conference on Digital Arts, Media and Technology (ICDAMT); IEEE: Chiang Mai, Thailand, 2017; pp 178-182.

https://doi.org/10.1109/ICDAMT.2017.7904957.

[5] Dell, K. A.; Chudow, M. B. A Web-Based Review Game as a Measure of Overall Course Knowledge in Pharmacotherapeutics. Currents in Pharmacy Teaching and Learning 2019, 11 (8), 838-842. https://doi.org/10.1016/j.cpt1.2019.04.012.

[6] Ismail, M. A.-A.; Ahmad, A.; Mohammad, J. A.-M.; Fakri, N. M. R. M.; Nor, M. Z. M.; Pa, M. N. M. Using Kahoot! As a Formative Assessment Tool in Medical Education: A Phenomenological Study. BMC Med $\begin{array}{llll}\text { Educ } & 2019, & 19 & \text { (1), }\end{array}$ https://doi.org/10.1186/s12909-019-1658-Z.

[7] Castro, M.-J.; López, M.; Cao, M.-J.; FernándezCastro, M.; García, S.; Frutos, M.; Jiménez, J.-M. Impact of Educational Games on Academic Outcomes of Students in the Degree in Nursing. PLoS ONE 2019, $14 \quad$ (7), e0220388. https://doi.org/10.1371/journal.pone.0220388.

[8] Aljezawi, M.; Albashtawy, M. Quiz Game Teaching Format versus Didactic Lectures. British Journal of Nursing 2015, $24 \quad$ (2), 86-92. https://doi.org/10.12968/bjon.2015.24.2.86.

[9] Borrell, J.; Cosmas, N.; Grymes, J.; Radunzel, J. The Effectiveness of Kahoot! As a Pre-Lesson Assessment Tool. 10.

[10] Suryandari, G.; Sudarmanto, AA. Kahoot! Application in Medical Education: A Fact for Student Motivation Level. Journal of Medico Legal-Ethics and Hospital Management 2020,9(2), 173-179.

https://doi.org/10.18196/jmmr.92128. 